\title{
CRIME AND CRIMINALITY
}

SOCIAL, PSYCHOLOGICAL, AND

NEUROBIOLOGICAL EXPLANATIONS 
This page intentionally left blank 
E H

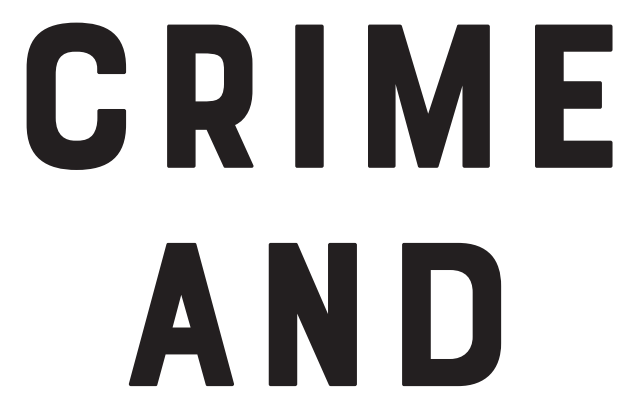

CRIMINALITY SOCIAL, PSYCHOLOGICAL, AND NEUROBIOLOGICAL EXPLANATIONS

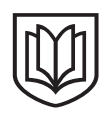

UNIVERSITY OF TORONTO PRESS 
Copyright (C) Ehor Boyanowsky 2020

University of Toronto Press

Toronto Buffalo London

utorontopress.com

Printed in Canada

ISBN 978-1-4875-0562-2 (cloth)

ISBN 978-1-4875-3243-7 (EPUB)

ISBN 978-1-4875-2389-3 (paper)

ISBN 978-1-4875-3242-0 (PDF)

All rights reserved. The use of any part of this publication reproduced, transmitted in any form or by any means, electronic, mechanical, photocopying, recording, or otherwise, or stored in a retrieval system, without prior written consent of the publisher-or in the case of photocopying, a license from Access Copyright, the Canadian Copyright Licensing Agency-is an infringement of the copyright law.

\section{Library and Archives Canada Cataloguing in Publication}

Title: Crime and criminality : social, psychological, and neurobiological explanations / Ehor Boyanowsky.

Names: Boyanowsky, Ehor, 1943- author.

Description: Includes bibliographical references and index. Identifiers: Canadiana 20190144009 | ISBN 9781487505622 (hardcover) | ISBN 9781487523893 (softcover)

Subjects: LCSH: Criminology. I LCSH: Crime. I LCSH: Criminal behavior. Classification: LCC HV6025 .B69 2019 | DDC 364.2—dc23

We welcome comments and suggestions regarding any aspect of our publications-please feel free to contact us at news@utorontopress.com or visit us at utorontopress.com.

Every effort has been made to contact copyright holders; in the event of an error or omission, please notify the publisher.

University of Toronto Press acknowledges the financial assistance to its publishing program of the Canada Council for the Arts and the Ontario Arts Council, an agency of the Government of Ontario.

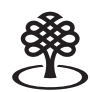

Canada Council for the Arts

Funded by the Government of Canada

Financé par le gouvernement du Canada
Conseil des Arts du Canada

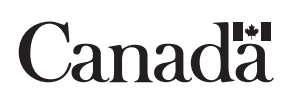

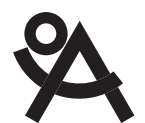

ONTARIO ARTS COUNCIL CONSEIL DES ARTS DE L'ONTARIO

an Ontario government agency un organisme du gouvernement de l'Ontario

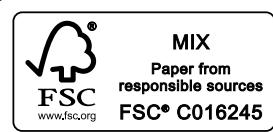


For Cristina, who insisted I persevere

In memoriam

Lesia Vera Dayneka, 1933-2019 
Nothing is easier than to condemn the evildoer; nothing is more difficult than to understand him.

—attributed to Fyodor Dostoyevsky

There are many evil systems, but few really evil people.

—Dmitri (Mike) Boyanowsky 